\title{
Alien plants in Poland: research directions and putting the results into practice
}

\author{
Barbara Tokarska-Guzik*, Katarzyna Bzdęga, Teresa Nowak, \\ Agata Lewandowska, Małgorzata Gancarek \& Małgorzata Frelich
}

Department of Plant Systematics, Faculty of Biology and Environmental Protection, University of Silesia, Jagiellońska 28, 40-032 Katowice, Poland

* corresponding author (e-mail: barbara.tokarska-guzik@us.edu.pl)

\begin{abstract}
The aim of this study was: $(i)$ to complete and verify the prior review of research on alien plants conducted in Poland and the practical use of their results, and (ii) to attempt to assess the contribution of the research from the area of Poland to the research conducted on an international level. The analysis was performed based on the information gathered during a literature search which covered the last 200 years, using over 1400 publications out of the 3000 which were available in the pool. As a result, the main areas of biological sciences in the context of the research undertaken on alien plants in Poland (distribution, ecology and biology of the species), the most common thematic studies (new species, new localities, and lists of alien species), and the most often investigated species, as well as tendencies over time were indicated. Although studies on the migration and distribution of alien plants in Poland have over 100 years of tradition, and the part of the studies conducted by Polish researchers contributes to the international scale research, it is still necessary to further analyse many issues and answer numerous questions.
\end{abstract}

Key words: alien species, research topics, bibliometric analysis, plant invasions, implementation, temporal trends, Poland

\section{Introduction}

Natural, economic and social threats associated with the spread of alien plants at regional, continental and global levels, and the tasks imposed on Poland resulting from its membership of the European Community, create an urgent need to introduce appropriate legal regulation and to develop source materials which could be used both in further research and in practical efforts to reduce this phenomenon. They are also crucial to assess the status and needs of the conservation of biological diversity, as the share of alien species in the floras of different regions of the world, including Europe, maintains an upward trend (e.g. Mooney 1999; Simberloff 2004; Lambdon et al. 2008; Pyšek et al. 2009; Butchart et al. 2010; Pimental 2011; Rabitsch et al. 2012).

To undertake remedial actions it is necessary to gather knowledge about alien species at the level of individual regions, including the identification and categorization of species which pose a threat and are defined as invasive (Tokarska-Guzik et al. 2011b). With regard to plants, among the preventive actions, the monitoring of alien species in individual regions is emphasized. Undertaken actions are based on identifying species in terms of the degree of their establishment, the possibilities of their spreading, and the potential adverse impact on other organisms and habitats. The results of these studies are then used for practical actions (prevention, control, combating, legal regulations and education) (Esler et al. 2010).

In addition to the traditional form of publishing the results of nature observations, nowadays other sources of information, including databases available on-line (e.g. European Network on Invasive Alien Species - NOBANIS, http://www.nobanis.org; the DAISIE (Delivering Alien Invasive Species Inventory for Europe), www.europe-aliens.org; and from Poland: Alien Species in Poland, http://www.iop.krakow.pl/), based on modern methods of data collection, elaboration, storage, processing, sharing and dissemination are also used (e.g. Zając 1978; Tykarski 2007; Kącki \& Śliwiński 2012; Chybiorz \& Tokarska-Guzik 2012; Trueman 2013). 
However, both basic and applied studies, implemented at many levels, may differ in terms of the scope, the degree of the accuracy and the frequency of undertaking. Even though "biological invasions are a hot research topic, the most information on the mechanism of invasion has emerged from work on a limited number of the most harmful invaders and only some naturalised species became the subject of a case studies" (Pyšek et al. 2008). It is only in recent decades that European society has drawn attention to the costs incurred as a result of alien plants spreading (conservation of biodiversity, protection of landscape and health, losses in different sectors of the economy) (Pyšek et al. 2006, 2009; Lambdon et al. 2008; Keller et al. 2011).

Despite the fact that scientists and decision-makers are becoming increasingly aware of the risks resulting from the spread of alien plants, variations in both the intensity (also in comparison with other developing research directions) and scope of the undertaken research and practical actions are still visible at the level of individual regions (countries). There are countries which have lists of alien plants and legal regulations together with related directives concerning their trade and management, while in other countries the knowledge and legislation related to this issue are limited (Shirley \& Kark 2006; Keller et al. 2011).

An attempt to summarize the main directions of the research on alien plants in Poland, in a historical context, was made by Tokarska-Guzik (2005), who at the same time pointed out important studies within the following thematic groups: (i) historical floras; (ii) new alien species; (iii) first reports in the country; (iv) synanthropic floras; $(v)$ detailed thematic studies with respect to distribution and biology, (vi) general and theoretical studies. It was also shown that significant contributions were made by those studies which concentrated on recording the appearance of new alien species in local floras and gathering data on their stations together with classification of plants accompanying humans and compiling checklist of species of alien origin occurring in Poland.

The aim of this study is to complete and verify the prior review of the range of research conducted in Poland related to alien plants, and the practical use of the research results, and additionally to attempt to assess the contribution of the research from the area of Poland to the research conducted at an international level.

\section{Methods}

The study was based on a literature search which covered the last 200 years based on: titles of studies, sets of keywords, citations, abstracts, available databases and websites. Subjects of interest included monographs, chapters of monographs and articles published in both
Polish and international journals; in the latter case, provided that they were related to Poland and/or at least one of the authors was affiliated to Poland. The review also covered regional thematic bibliographies (e.g. Celka \& Jackowiak 1998; Jackowiak \& Latowski 1996, 2001; Ziarnek et al. 2003) and available conference papers, reports and communications of other types. All the initially gathered studies were submitted to a multistage selection based on the keywords, classification of alien species, and their belonging to the selected and/or dominating research direction. The analyses covered studies which included the terms: 'synanthropic', 'anthropogenic', 'ruderal', 'segetal' (species, flora, vegetation, plant community), and also 'alien species', 'species of foreign origin', 'non-native species', 'non-indigenous species', 'exotic' and 'established/naturalised species' in Polish or their English equivalents in their titles and/ or keywords.

Further analyses were based on the studies selected according to the alien species classification adopted in Poland (Tokarska-Guzik et al. 2012 and references cited therein), taking into account the classification of the English-language literature (Richardson et al. 2000; Pyšek et al. 2004), using the following words: 'archeaeophyte', 'kenophyte', 'neophyte', 'ephemerophyte', 'invasive species' and 'weed'. Further categorization of publications concerned basic research directions; here again the terms included in the title and/or keywords of the analysed item and objectives outlined by the author were used as words-identifiers (Table 1).

The created database contained over 3000 items, and eventually 1423 of them were used in the analysis, excluding historical studies, published before 1945 (not used because they constituted the low percentage of a whole dataset and also that the greatest interest of this study was focused on recent trends in research on alien plants; however they were partly included in the list of selected papers attached to this study - Appendix 1), as well as classic regional and local floras and popularscientific publications. The range of the collected information covered: $(i)$ the title of the publication; (ii) the author(s); (iii) the year of publication; (iv) the keywords specified by the author of the publication, $(v)$ the type of source (monograph, journal, website); ( $v i$ ) the category of the study specified by the author (the direction of research); (vii) the information about the availability of the study in the form of a pdf file or on-line.

\section{Results}

Studies on alien plant species in Poland occur in many disciplines of the biological sciences (e.g. aerobiology), especially including some parts of botany, such as: geobotany (plant ecology, phytogeography and phytosociology), plant genetics, plant molecular 
Table 1. Categorization of scientific publications from the scope of alien plant species in Poland, on the base of most frequently used 'word identifiers' in keywords and title of the work

\begin{tabular}{|c|c|c|}
\hline $\begin{array}{l}\text { The main category } \\
\text { of analysed works/ } \\
\text { papers }\end{array}$ & Subcategories & Selected 'word identifiers' \\
\hline Distribution & $\begin{array}{l}\text { - maps and atlases } \\
\text { - new locality/ localities } \\
\text { - new species }\end{array}$ & $\begin{array}{l}\text { distribution, locality/localities, map/maps, } \\
\text { occurrence, range, new anthropophyte, new } \\
\text { casual plant, new holoagriophyte, new kenophyte, } \\
\text { new synanthropic plants }\end{array}$ \\
\hline Biology & $\begin{array}{l}\text { - aerobiology } \\
\text { - germination } \\
\text { - reproduction }\end{array}$ & $\begin{array}{l}\text { acclimatization, aerial plankton, allergen, } \\
\text { biological properties, germination, mycorrhiza } \\
\text { (arbuscular mycorrhizal fungi), nectaries, } \\
\text { phenology, pollen (grains), pollination, } \\
\text { regeneration, reproduction (generative, } \\
\text { vegetative), seed viability, seed dispersal }\end{array}$ \\
\hline Ecology & $\begin{array}{l}\text { - allelopathy } \\
\text { - habitat } \\
\text { - influence } \\
\text { - new plant community } \\
\text { - soil seed bank } \\
\text { - species interactions }\end{array}$ & $\begin{array}{l}\text { allelopathic potential, autekology, biotic and } \\
\text { abiotic factors, competition, community, } \\
\text { functional groups, habitat requirements, impact, } \\
\text { natural enemies, new plant association, soil seed } \\
\text { bank, stress, succession, vegetation change }\end{array}$ \\
\hline $\begin{array}{l}\text { Genetics and } \\
\text { cytogenetics }\end{array}$ & $\begin{array}{l}\text { - genetic diversity } \\
\text { - genetic structure } \\
\text { - genome size } \\
\text { - hybridization } \\
\text { - molecular analysis } \\
\text { - ploidy level }\end{array}$ & $\begin{array}{l}\text { chromosome/chromosomes number, cytology, } \\
\text { genetic complex, genotype, hybridization/in } \\
\text { situ hybridization, hybrids, genetic diversity, } \\
\text { karyology, karyotype structure, molecular } \\
\text { markers, polyploidy, sex }\end{array}$ \\
\hline Nature protection & $\begin{array}{l}\text { - control } \\
\text { - invasive plants management } \\
\text { - monitoring } \\
\text { - prevention } \\
\text { - threatened weeds }\end{array}$ & $\begin{array}{l}\text { biodiversity, degree of threat, endangered species, } \\
\text { good practices, herbicides, risk assessment }\end{array}$ \\
\hline $\begin{array}{l}\text { Interdisciplinary } \\
\text { studies (including } \\
\text { applied botany) }\end{array}$ & $\begin{array}{l}\text { - methodological and theoretical } \\
\text { works } \\
\text { - classifications } \\
\text { - lists } \\
\text { - bibliographies (e.g. reviews) } \\
\text { - applications: agriculture, forestry, } \\
\text { medicine, energy, horticulture, } \\
\text { reclamation }\end{array}$ & $\begin{array}{l}\text { biofuel, biomass calorific value cultivation, } \\
\text { energy crops, fodder crops, methodological } \\
\text { problems, medicinal plants, melliferous plants, } \\
\text { renewable energy resources, vegetable raw } \\
\text { materials }\end{array}$ \\
\hline Others & $\begin{array}{l}\text { - taxonomy } \\
\text { - physiology }\end{array}$ & $\begin{array}{l}\text { anatomy, carpology, growth, morphology, } \\
\text { productivity, photosynthesis, systematics }\end{array}$ \\
\hline
\end{tabular}

Explanations: the following keywords: alien, anthropogenic, anthropophyte, archeaeophyte, ephemerophyte, established, invasive species, kenophyte, naturalised, neophyte, non-native species, non-indigenous species, ruderal, segetal, species of foreign origin, synanthropic, weed, were used for preselection of the publications

cytogenetic, nature conservation, and plant taxonomy; less often plant anatomy, morphology and physiology. Particularly common are the studies in the field of phytogeography (new localities, distribution on different scales, maps of ranges), ecology (ecological requirements, impact on biotic and abiotic conditions, interspecific interactions, soil seed bank) as well as genetics and cytogenetic (genetic structure of a population, genetic variability, genome size, ploidy level, molecular analysis of hybrids), and less frequent are the studies which concern: biology (ways of reproduction and its efficiency, dispersal mode and regeneration capacity), or taxonomy and phylogenetics. Separate and distinct group is formed by interdisciplinary studies (Fig. 1A, see also Appendix 1).

It should be noted that in the second half of the twentieth century efforts were focused primarily on the collection of data on the distribution of species, while in recent years the number of studies in the field of the ecology and biology of species has increased (Fig. 1B). Anthropogenic transformations of vegetation were a research subject for Polish botanists as early as in the 

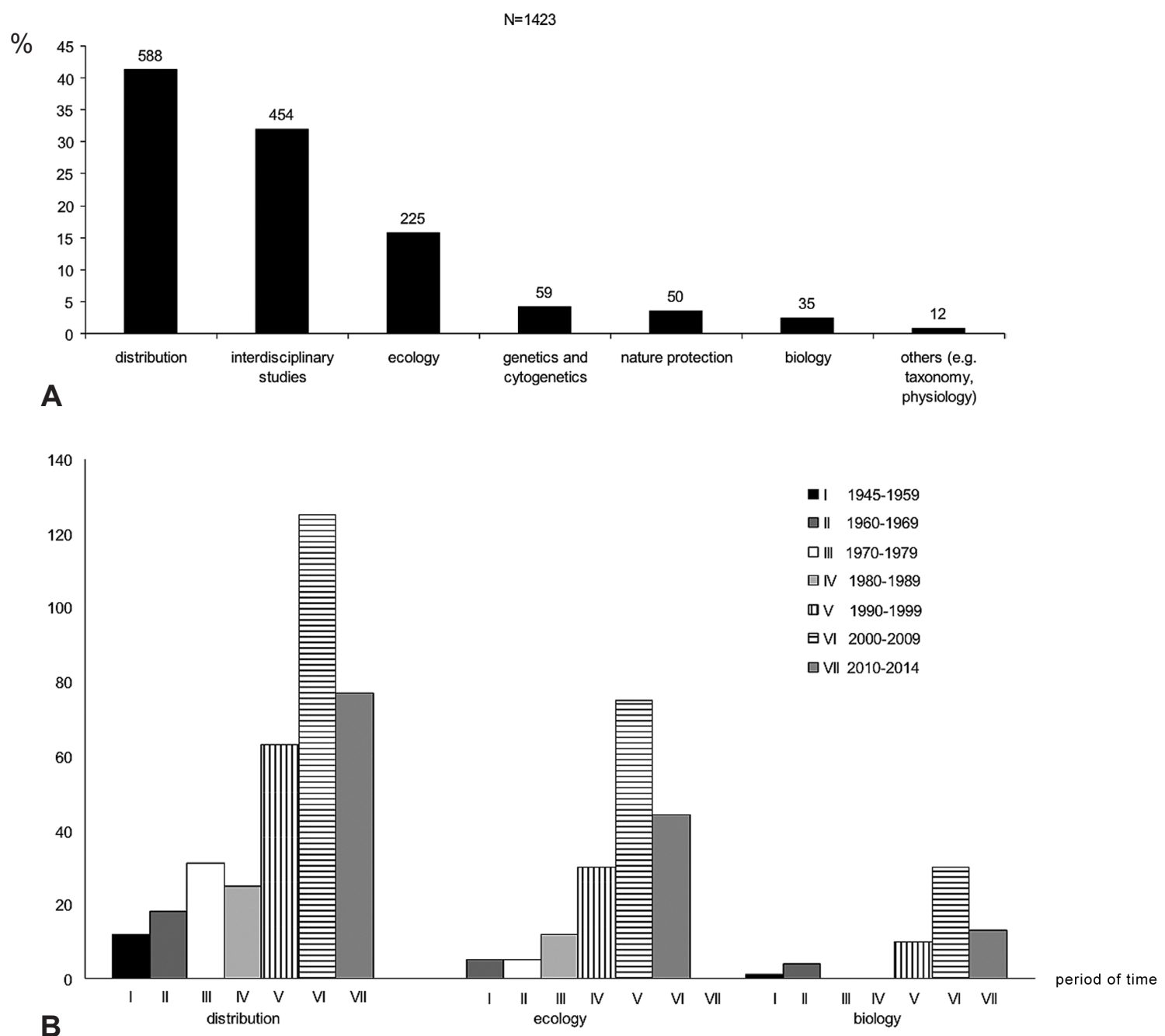

Fig. 1. Contribution of studies pertaining to alien plant species conducted by botanists in Poland in the selected fields of natural sciences (A) and changes in the frequency of undertaken studies in the subsequent periods of time (B)

1960s. Since that time many descriptions of regional floras, and studies on floras associated with different types of anthropogenic localities (ruderal, segetal), which contain information relating to alien species have been published. Among numerous publications belonging to the mainstream research on synanthropiza-

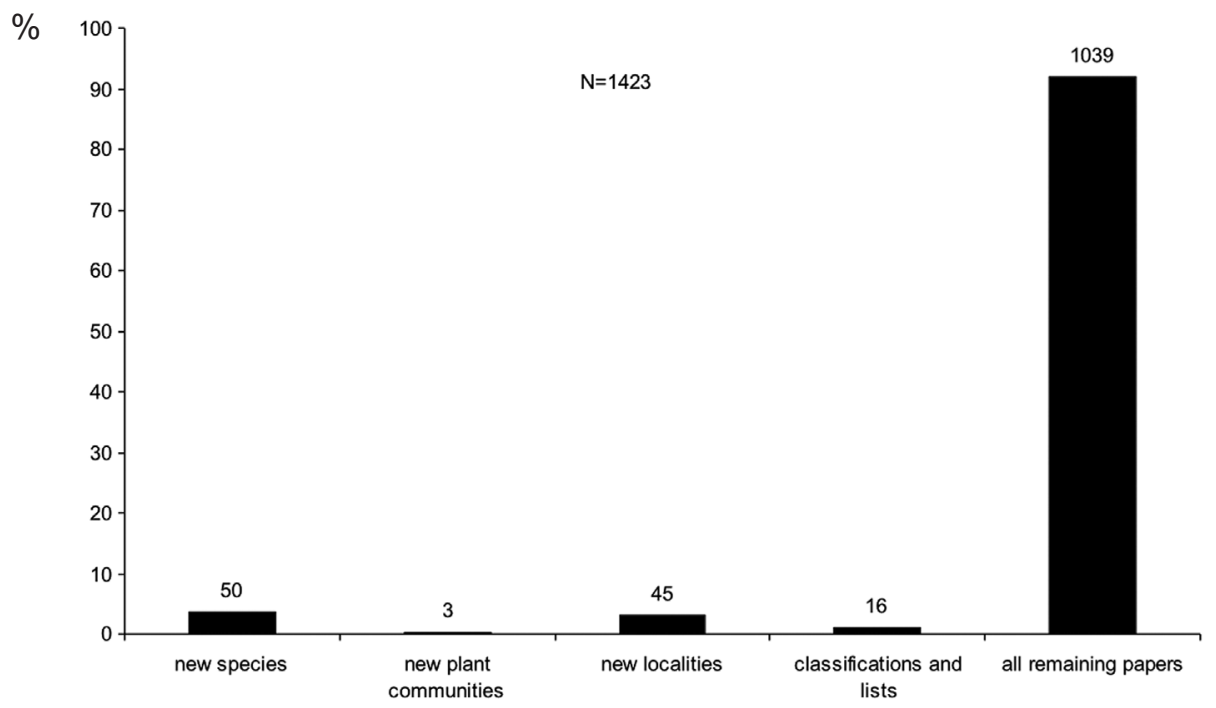

Fig. 2. Contribution of particular topics of studies pertaining to alien plants more frequent published in Poland in the total number of papers analysed 


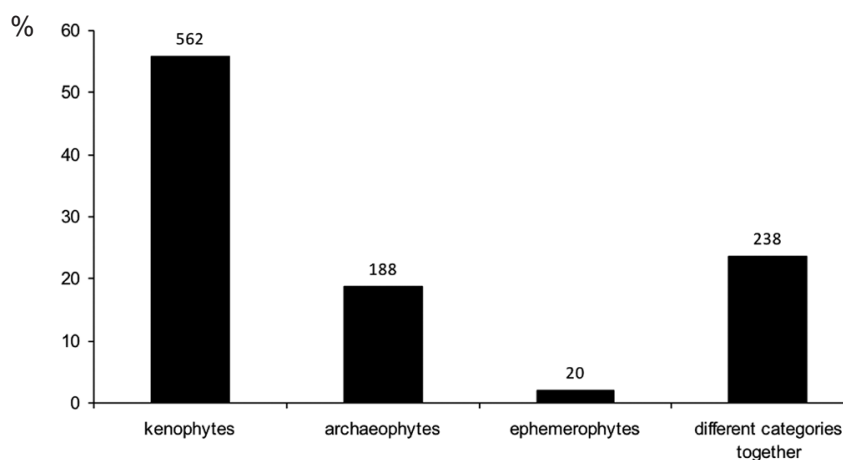

Fig. 3. A comparison of number of publications dedicated to selected groups of alien plant species in Poland

tion of vegetation, especially distinctive are studies which characterise new alien plant species appearing in the Polish flora, as well as reports on new localities of alien species, and classifications of adventive flora and lists of alien plant species (i.e. anthropophytes according to Sudnik-Wójcikowska \& Koźniewska 1998; also Kornaś 1981 and Tokarska-Guzik 2005) (Fig. 2).

Publications describing individual groups of anthropophytes are dominated by studies on species arrived and became permanently established after 1500 - kenophytes (over $55 \%$ of the studies), less often to species anciently established - archaeophytes (over 18\%), and the least popular are studies concerning casual alien plants - ephemerophytes (about 2\%) (Fig. 3). These are both studies on individual species (case studies) and on their groups, as well as theoretical and synthetic studies (classifications, lists, models). In the case of archaeophytes, the majority of publications describe disappearing species. Subsequent decades saw a growing interest in the study of permanently established alien plants, and the last fifteen years have seen a focus on the rapidly spreading and pose significant threat kenophytes (Fig. 4). So far the studies covered in total about 200 species of alien plants. The completed and updated list permitted us to select the most investigated genera and species. They include archeaophytes: Avena fatua (28 publications), Echinochloa crus-galli (19) and Alopecurus myosuroides (13), kenophytes: species of genus Heracleum (46; including $H$. sosnowskyi - 33), Impatiens (36; including I. parviflora - 20, I. glandulifera14) Oenothera (30), Solidago (24) and Reynoutria (20), as well as Padus serotina (35), Aesculus hippocastanum (24) and Anthoxanthum aristatum (18) (Fig. 5a and b). It is worth noting that a comparable interest is directed at some of the species which nowadays are considered to be locally established, e.g. Mahonia aquifolium and Aronia melanocarpa. The studies on Mahonia aquifolium concentrate on its use as an ornamental plant, but also on the analysis of its colonisation process of different types of habitats, as well as the biology and ecology of this species. Aronia melanocarpa, which was covered by a similar number of studies collected in the database, is primarily of interest to medical, agricultural and forest science.

Publications regarding 'applied botany' were selected from the analysed studies. Over $50 \%$ of them were the subject of interest to agricultural botany, and then also to forest and pharmaceutical botany (Fig. 6). Another subject of numerous publications was the identification of alien plants, their geographical-historical classification, and their status of establishment. One of the examples of results presentation are the lists of species, both at national and regional levels, often taking into account the knowledge about their biology and chorology. In the longer term, a constant interest in research relating to alien species spreading in rural

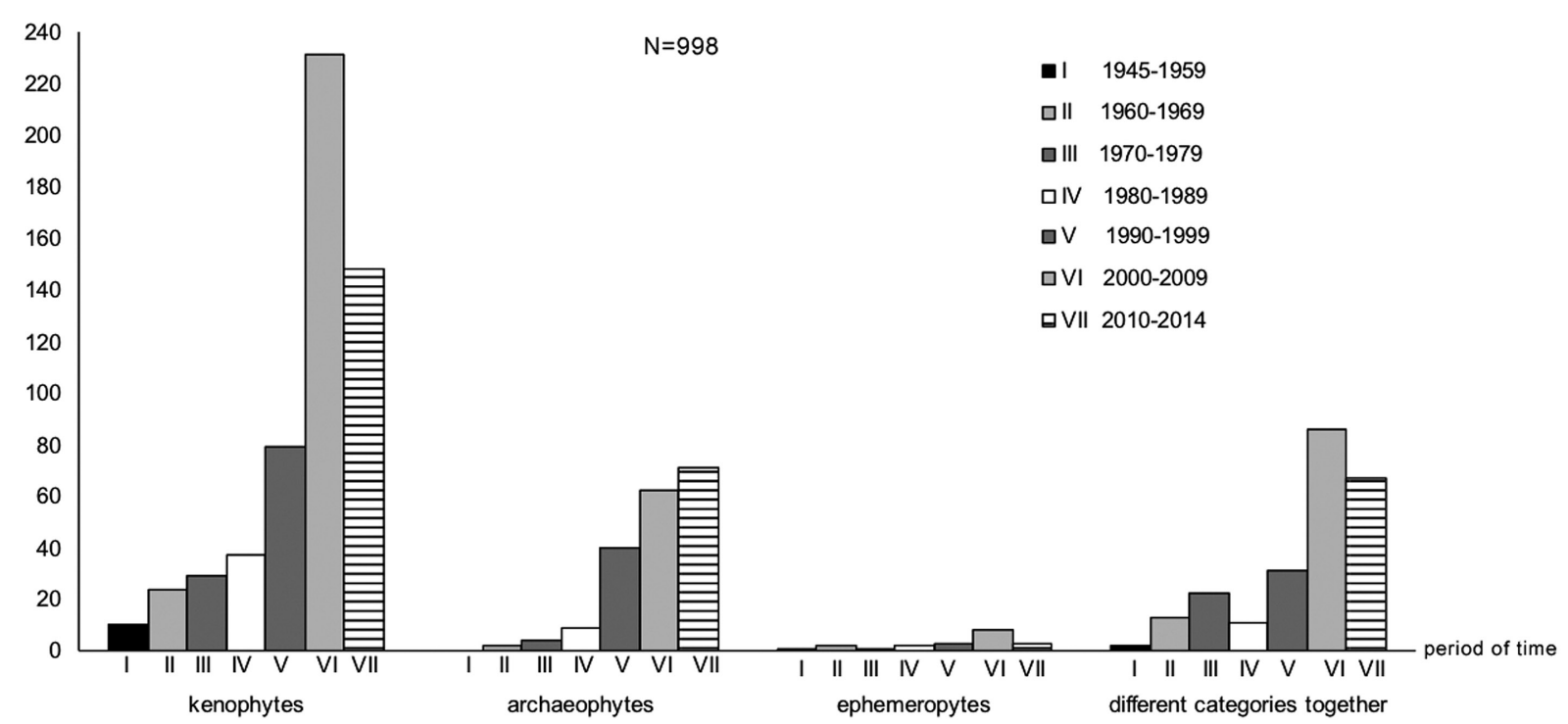

Fig. 4. Temporal trends in the number of scientific papers pertaining to selected groups of alien plant species 


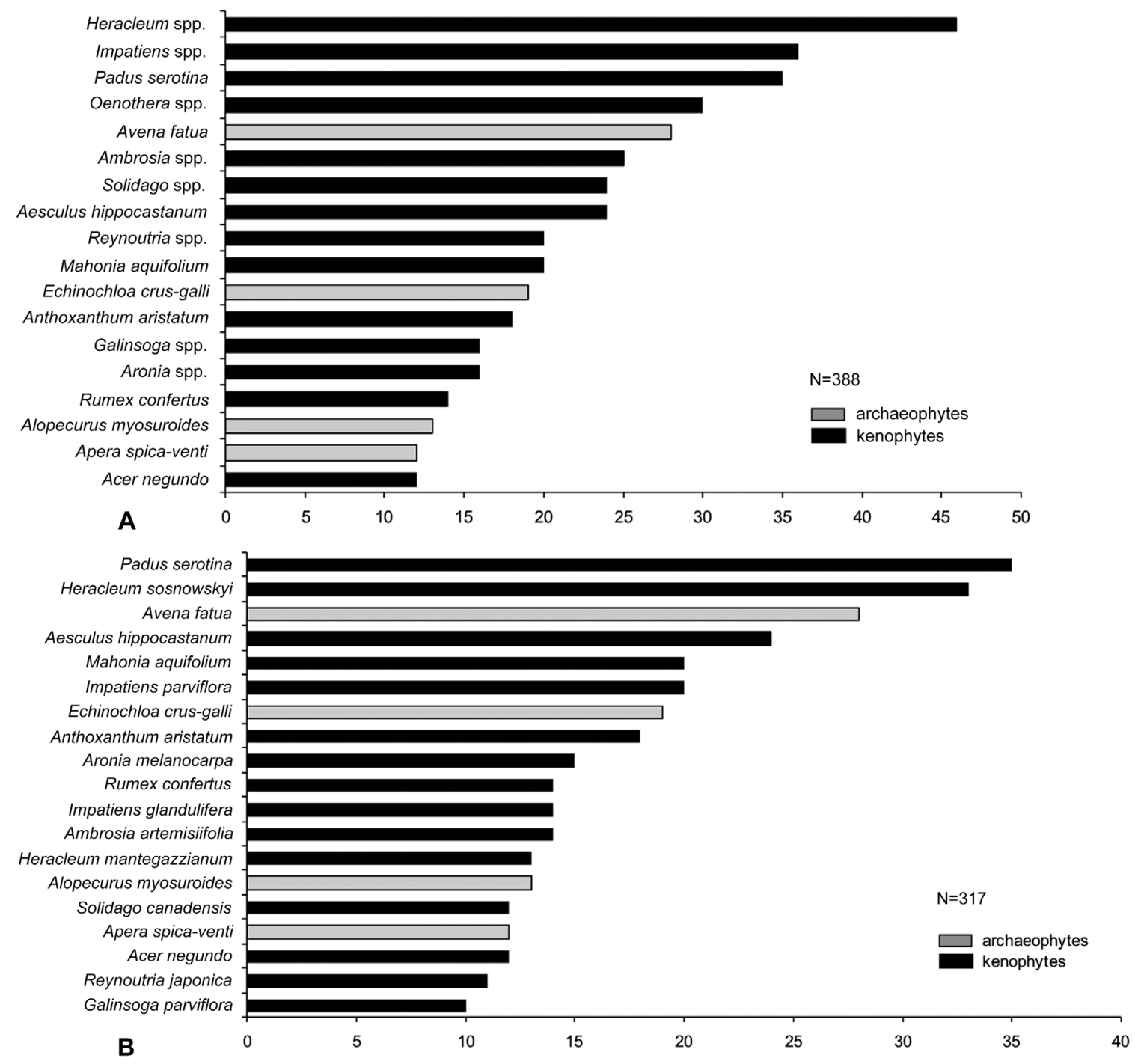

Fig. 5. The most frequently investigated genera and species of alien plants in Poland

Explanations: A - selected species were counted jointly within genera, B - exclusively species were counted

areas (weeds), expressed as a gradual increase in the number of publications (Fig. 7A), is discernible, while an increased interest in research on invasive species is clearly visible, especially over the last 15 years (Fig. 7B). The state of the art is significantly organized by theoretical studies which arrange the terminology and

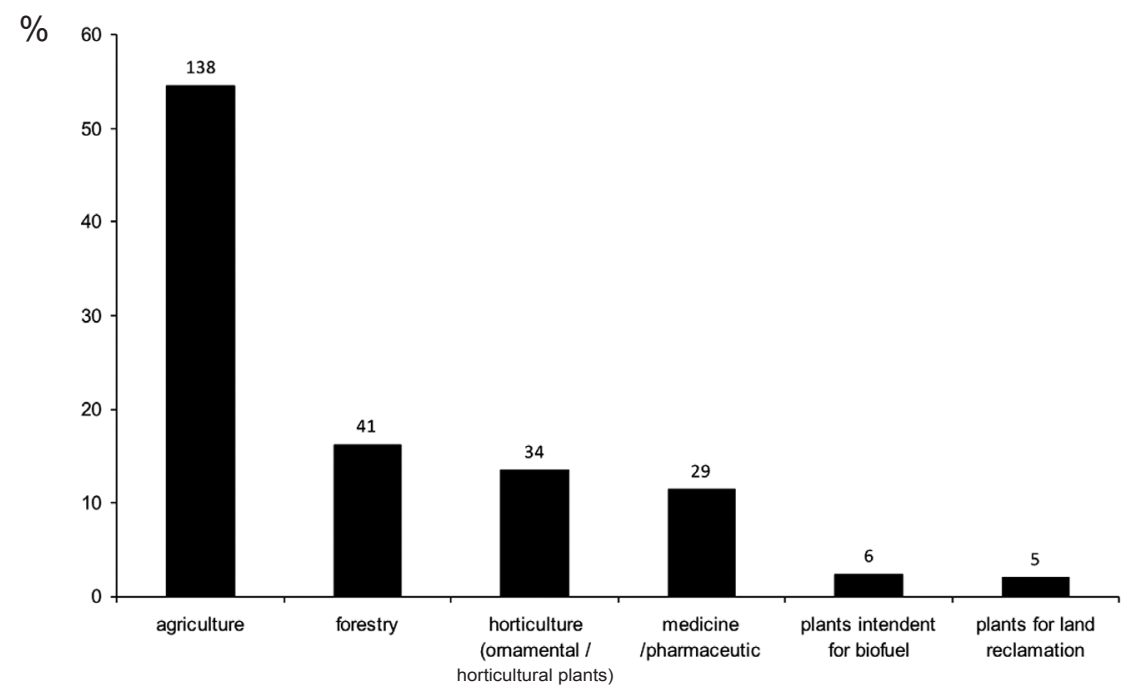

Fig. 6. Studies on alien plant species in Poland being of interest to applied botany and other human activities 

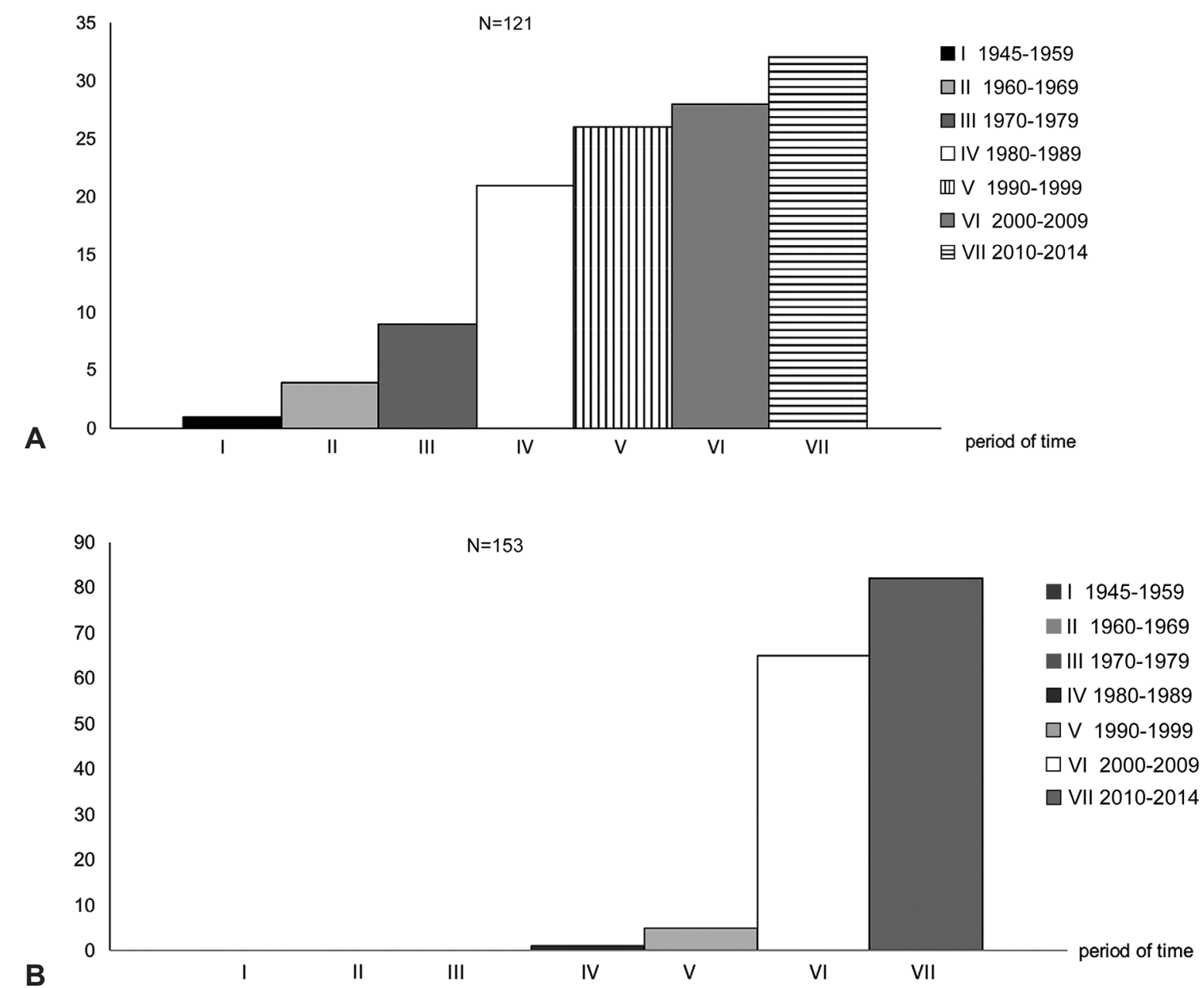

Fig. 7. The change in number of studies pertaining to spreading alien plants species: weeds (A) and invasive species (B) developed by botanists in Poland

describe the models of the invasion phenomenon, its causes and consequences, and are illustrated by examples. However, they are not conducted frequently (model species, invasive species with a broad range, modelling of ranges).
The results of the analysed studies were published in the form of scientific papers (about 68\%), monographs and chapters of monographs (4\%), as well as conference papers and reports and communications of other types (28\%) (Fig. 8). Studies in Polish dominate (over 1000),

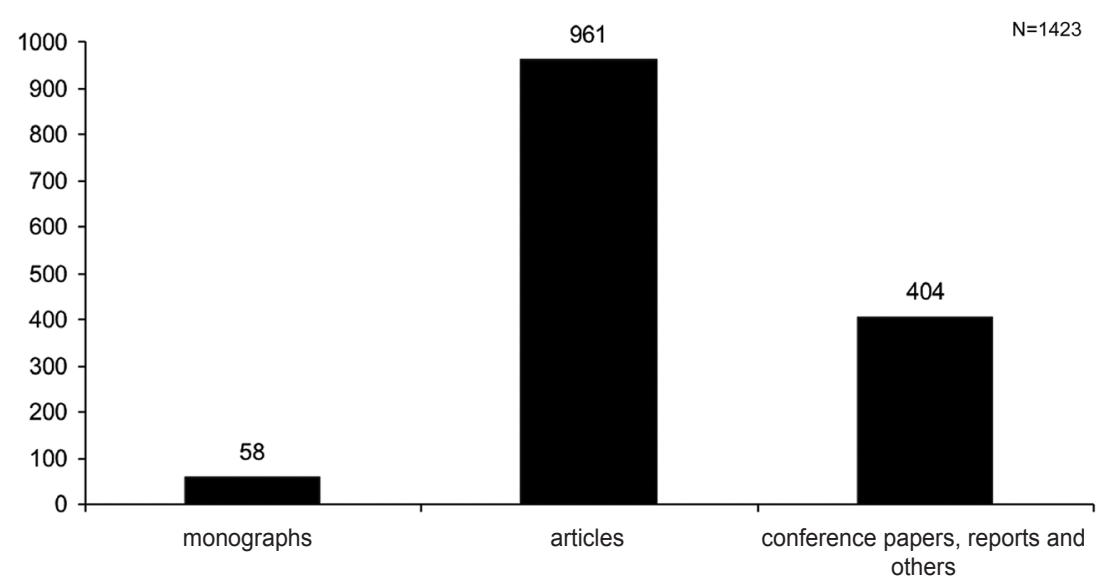

Fig. 8. Types of the publication of study results concerning different aspects of synanthropization, with particular reference to alien plant species occurring in Poland 


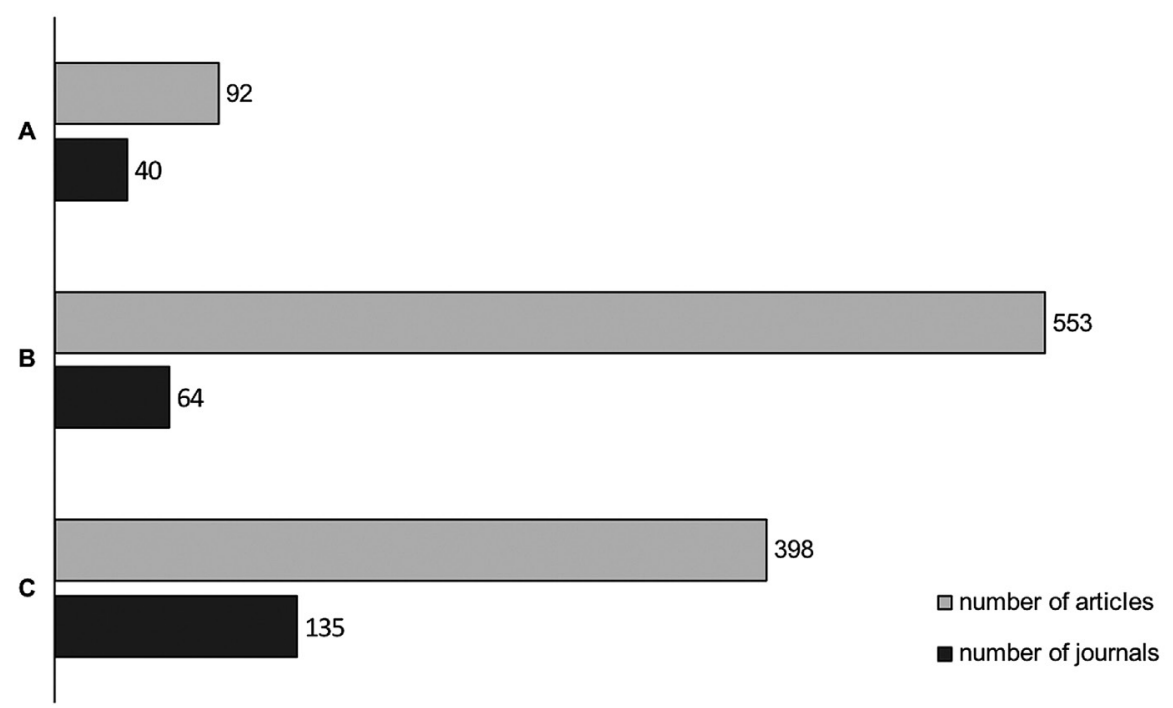

Fig. 9. Overall view of meaning and the scope of the influence of publications devoted to alien plants delivered by botanists in Poland Explanations: A - scientific journals of international range, B - scientific journals of regional and national range, $\mathrm{C}$ - scientific journals of local range

although the increase in English-language publications is noticeable. Most of the studies were published in journals of regional or national range; few of them can be considered to have a wider range. The studies were mostly published in journals from the list of scientific journals available on the website of the Ministry of Science and Higher Education, with the IF or without this factor (lists A and B) (Fig. 9), and most of them are also available on websites (about $30 \%$ of the analysed publications) Out of 1423 analysed papers there are 426 articles available in the electronic version (as pdf) or as links (42 positions). Among the publication about the international reach focused on anthropogenic changes in plant cover, including plant invasions, it is possible to indicate for example studies cover the field of genetics (Bzdęga et al. 2012; Góralski et al. 2014), cytogenetics (Drapikowska et al. 2013), the biology of mycorrhiza (Chmura \& Gucwa-Przepióra 2012), and the transformation of vegetation (Woźniak et al. 2011), as well as aerobiology (e.g. Stępalska et al. 2002; Kasprzyk et al. 2011), distribution and habitat preferences (Galera \& Sudnik-Wójcikowska 2000a, 2000b; Wrzesień 2007; Nobis et al. 2006; Tokarska-Guzik et al. 2010; Pielech et al. 2012; Pliszko 2013), biology and ecology of species (Moroń et al. 2009; Lenda et al. 2011; Tokarska-Guzik et al. 2011a; Adamczewski et al. 2013; Chmura et al. 2013; Sołtysiak \& Brej 2014).

\section{Discussion}

Studies on the migrations and distribution of alien plant species both in Poland and in other European countries have already had a certain tradition, ranging from the studies on selected species or regions (flora of specific areas, cities, specific types of anthropo- genic habitats) to the studies covering entire countries (Tokarska-Guzik 2005 and references cited therein; e.g. Dyakowski 1899; Kobendza 1930; also Latowski et al. 2010; Jackowiak et al. 2013 and Pyšek et al. 2012a, $2012 \mathrm{~b}$ and references cited therein), and recently they have also synthesised the results on larger scale of geographical regions and continents (e.g. Vilà et al. 2010). The effect of human historical impact on vegetation, and especially on the flora, is reflected in the best way by the relationship between two groups of species: native and alien ones, and, within the group of alien ones, by the relationship between the 'oldest human companions', that is archaeophytes, and 'newcomers', that is kenophytes (Tokarska-Guzik 2005). This thesis is confirmed by a number of studies undertaken in this field.

The issue of the origin and development of ranges of the oldest anthropophytes occurring in Poland, that is archaeophytes, was addressed by Zając in his basic monograph (1979) and detailed reports (1983, 1987a, 1987b, 1988), while for the newer arrivals, that is kenophytes, the same task was fulfilled by detailed maps published in "The Atlas of distribution of vascular plants in Poland" (Zając \& Zając 2001) and the monograph by Tokarska-Guzik (2005). These studies have recently been updated with a publication describing ephemerophytes, the plants which are not permanently established in the Polish flora (Urbisz 2011).

Continuous transformations of the vascular plant flora in Poland, new results of the studies on anthropophytes, as well as reported practical reasons created a need to develop an original, up-to-date catalogue (list) of alien plant species occurring in Poland. The publication "Alien plants in Poland with particular reference to invasive species" (Tokarska-Guzik et al. 2012) was aimed at filling this gap. This publication contains 
basic information on the phenomenon of the spread of alien species in Poland, together with definitions and terminology of invasion ecology applied in Poland on an international background; it also presents contemporarily applied classifications of alien plants.

In addition, an important complement to the knowledge in this field are atlases illustrating the distribution of individual species on different scales, including "The Atlas of distribution of vascular plants in Poland" (Zając \& Zając 2001) cited above, a book crowning many years of work by numerous botanists, which represents a synthesis of our knowledge about the spatial properties of Polish flora (Olaczek 2001). The atlas covers 90\% of the species of Polish flora, including the majority of alien species established in Poland (Tokarska-Guzik 2005). These studies gathering the knowledge referring to the current status of particular alien species in the flora of the country and its distribution range can be of help in developing future research. The collection of current knowledge about alien species in Poland was possible thanks to numerous detailed studies, which are regularly supplemented (e.g. Piwowarski \& Bartoszek 2012; Malicki et al. 2013).

Because of the threats created by certain species of alien plants to the native vegetation, in recent decades interest in biological invasions has increased, and as a result the issue of alien species invasion, benefitting from different scientific disciplines, has emerged as a separate stream of research (e.g. Rejmánek 1996; Daehler 2001). The research programmes devoted to alien plant species are currently focused on the assessment of the risk to the native vegetation resulting from the invasion of alien species (numerous basic research studies in the field of taxonomy, biology and ecology of the species and nature conservation), as well as the methods and techniques enabling the control of invasive species spread (cartographic distribution studies, monitoring, management and control methods) (Pyšek 1995; Daehler \& Carino 2000; Hulme et al. 2013). Although the interest of the botanists in Poland covers the research range mentioned above, it is significantly dominated by chorological studies. According to findings delivered by Pyšek et al. (2008) similarly in Poland the highest number of undertaken studies is limited to the most harmful alien plants (considered as 'invasive' or 'weeds') or is of interest of other scientific disciplines (e.g. taxonomy - Oenothera spp.).

To summarise, it can be concluded that the research conducted in Poland relating to the issues of synanthropization of vegetation are a part of general directions undertaken on the level of other regions (countries), with a clear trend to focus attention on segetal floras and biological invasions. Special issues analysed by Polish botanists, which became a permanent contribution to biogeographical science indicated by Tokarska-Guzik (2005), and which deserve to be recognized, are:

- model monographs on anthropogenic transformations of vegetation in the Gorce mountains (Kornaś 1955) and Białowieża Forest (Faliński1966a);

- pioneering attempts at a comparative analysis of the floras in towns and settlements (Faliński 1971; Krawiecowa \& Rostański 1976);

- methodological and problem-focused studies on the spatial structure of urban flora (Jackowiak 1998a, 1998b; Sudnik-Wójcikowska 1998a), especially the model solutions of Jackowiak (1998a, 1998b), defining a big city as a centre for the crystallization of floristic and ecological space, and Sudnik-Wójcikowska (1998a, $1998 \mathrm{~b}, 2000)$, confirming the indicative role of flora in relation to the thermal conditions of an urbanized area; - comparisons of diversities of ruderal floras in special areas, treated as 'environmental islands': medieval fortified settlements (Celka 2011), settlements located in agricultural and forest areas (Wołkowycki 2000), and post-industrial wastelands (Rostański 1998a, 1998b; Woźniak 1998; Cohn et al. 2001);

- assessment of abiotic and biotic factors affecting the diversity of ruderal vegetation (Kompała-Bąba 2013); - theoretical concepts (models) interpreting the phenomena of ecological and geographical expansion (Jackowiak 1999; Faliński 2000, 2004) (see also Appendix 1).

The most important theoretical and synthetic publications are the numerous studies of Kornaś (1981, 1982, 1983, 1990, 1996), Faliński (1969, 1972, 1998a, 1998b, 1998c, 2000, 2004), Zając \& Zając (2000), and Jackowiak $(1999,2000,2003)$ (see also Appendix 1).

As in other regions of Europe the terminology was set in order, the status of geographically alien species occurring in Poland was identified and verified, the original catalogue of alien plant species occurring in Poland was developed, the list of invasive plant species for Poland was prepared, the categorisation of alien invasive plants along with a suggestion for the most endangered types of natural habitats was conducted, maps of ranges for dozens of alien species occurring in Poland were created, and also the synthesis of existing knowledge on the formation of synanthropic floras was made, and an attempt to reconstruct historical changes of kenophyte ranges within the area of Poland was performed (Zając \& Zając 2001; Tokarska-Guzik 2005; Tokarska-Guzik et al. 2011b, 2012 and references cited therein).

Due to the fact that the problem of biological invasions is currently one of the most significant global hazards for nature, it is increasingly discussed and investigated in different forms, which result in an increase in the number of studies, especially interdisciplinary 
ones. At the same time some authors also pointed that cross-taxonomic articles - although comprising a greater proportion of articles published in ecology as a whole - are rare in invasion biology and have not increased over time (Jeschke et al. 2012). The main aspect of the studies seems to be the biology and ecology of the species (including, more and more often, natural enemies). It is believed that the increasing demand for the results of such research will contribute both to their practical application (especially for the control of the invasive species populations), as well as to generate further studies. Species of plants classified as invasive, especially those with no determined impact on native diversity, require further studies (in the fields of basic research, and studies on predicting the invasion and evolution processes caused by invasions of alien species). For example, out of 72 species classified in Poland as invasive (Tokarska-Guzik et al. 2012), several were the subject of frequent analyzes. Taking into consideration the relationship of invasive species with types of natural habitats, which they penetrate and whose biodiversity they affect, within protected habitats, 38 types, in which individuals of at least one of the selected invasive species were observed, were indicated. Over $80 \%$ of them appear at least in one protected natural habitat (Tokarska-Guzik et al. 2012). However, the detailed type of their impact was neither determined nor confirmed by any study. Moreover, there is no full information about the applied importance of these plants in different areas of human life and activity.

Poland is among the countries which represent positive trends in terms of adopted legal solutions relating to alien species (Butchart et al. 2010). However, there are still some failures in this regard. There are few studies which link theory and practice, and they are often aimed at raising public awareness (published on the website of the Institute of Plant Protection, or the General Directorate for Environmental Protection). There is also little information about the applied importance of alien plants in different areas of life. Nowadays, numerous entities (public administration, enterprises, scientists and private individuals increasingly benefit from spatial databases or geoportals which present this type of data (Białousz 2013; Tokarska-Guzik et al. in press).

Natural science research is fundamental to human survival and the preservation of nature in a possibly unchanged condition, while the results of this research, available to the public in databases and geoportals, constitute an effective tool for managing natural resources and involving society (e.g. Geneletti 2004; Walczak 2011; http://www.iop.krakow.pl/). In addition, the combination of modern tools in the field of photogrammetry and remote sensing, and knowledge accumulated in the descriptive form in databases, allows, by overlapping information from various sources and combining facts, the performance of both new cognitive and applicative analyses (e.g. Dewey et al. 1991; Thuiller et al. 2005; Dorigo et al. 2012; Wasowicz et al. 2014). Therefore, it seems necessary for Polish botanists to undertake studies in this area.

Although the research undertaken in Poland is not well represented in the literature at an international level, the range of undertaken research confirms the thesis that the phenomenon of biological invasions is inherently a multi-disciplinary issue, and the results obtained in this type of research can bring new answers which are also applicable to other disciplines. According to Keller et al. (2011) many researchers have been attracted to study species invasions because of the complexities, and the possibility to integrate across disciplines in ways that both generate new insight and that can lead to practical policy solutions.

All that is however not sufficient recently and is particularly true for Polish conditions. The newest recommendations, based on recent advances in invasion science, are pointing out the need to trigger a multi-pronged research strategy by using: 'model system research', 'multi-site studies' and 'focused metaanalysis'(Kueffer et al. 2013).

\section{Conclusions}

The conducted analysis, despite the fact that it was limited to a sample of about 1400 sources due to the applied criteria of publication selection, allows the signalling of a trend in the study of alien species occurring in Poland:

The assessment of the status and scope of the undertaken research, and the practical use of these results, indicate an upward trend in basic research, and also partially in practical activities (defining groups of target species, progress in activities related to the monitoring of this group of species, e.g. by developing the national database of the Institute of Nature Conservation PAS, and creating regional databases).

It seems that the group of archaeophytes occurring in segetal communities is relatively well studied and covers many aspects. This is due to the fact that they are also of interest to agricultural sciences.

The species of plants classified as invasive, especially those whose impact on native biodiversity has not been determined, require further investigation.

An important aspect of the research, fitting well a broadly defined ecology of invasions, interfacing with the possibilities of the practical use of the results, should be a determination of the role of biological control in limiting the spread of invasive plants (characteristics of the natural enemies of these plants from different taxonomic groups, and their impact on native elements of the flora). 
Comprehensive, multi-faceted and multi-level studies relating to phenomena and species providing model solutions which could be used in practice are few.

Urgent tasks include creating a scientific basis for the development of early warning systems, and the selection of appropriate methods to eliminate or limit the population of the most 'harmful' plant species (combating and/ or control), as well as the dissemination/promotion of information on the importance, hazards and possibilities for prevention of invasions in different social groups (education).
Acknowledgements. We wish to thank anonymous reviewers for their valuable comments and suggestions. This work has been partially supported by the project no. NN 305384738, financed by the Polish Ministry of Science and Higher Education and by institutional long-term research project "Alien invasive species in the flora of Poland: risk assessment for the native biodiversity" from the University of Silesia, Faculty of Biology and Environmental Protection, Department of Plant Systematics.

\section{References}

(The publications cited exclusively in the text)

AdamcZewski K., Kierzek R. \& Matysiak K. 2013. Wild oat (Avena fatua $\mathrm{L}$.) biotypes resistant to acetolactate synthase and acetyl-CoA carboxylase inhibitors in Poland. Plant Soil Environ. 59(9): 432-437.

BiaŁousz A. (ed.). 2013. Informacja przestrzenna dla samorządów terytorialnych. Oficyna Wydawnicza Politechniki Warszawskiej, Warszawa.

Butchart S. H. M, Walpole M., Collen B., van Strein A., Scharlemann J.P.W., Almond R.E.A., Baillie J.E.M., Bomhard B., Brown C., Bruno J., Carpenter K.E., Carr G.M., Chanson J., Chenery A.M., Csirke J., Davidson N.C., Dentener F., Foster M., Galli A., Galloway J.N., Genovesi P., Gregory R.D., Hockings M., Kapos V., Lamarque J-F., Leverington F., Loh J., McGeoch M.A., McRae L., Minasyan A., Morcillo M.H., Oldfield T.E.E., Pauly D., Quader S., Revenga C., Sauer J.R., Skolnik B., Spear D., Stanwell-Smith D., Stuart S.N., Symes A., Tierney M., Tyrrell T.D., VIÉ J-C. \& WATSON R. 2010. Global Biodiversity: Indicators of Recent Declines. Science 328: 1164-1168.

Bzdęga, K., Janiak A., TarŁowska S., Kurowska M., TokarSKA-GuZIK B. \& SzaREJKo I. 2012. Unexpected genetic diversity of Fallopia japonica from Central Europe revealed after AFLP analysis. Flora 207: 636-645.

CELKA Z. 2011. Relics of cultivation in the vascular flora of medieval West Slavic settlements and castles. Biodiv. Res. Conserv. 22: 1-110.

Celka Z. \& Jackowiak B. 1998. Bibliography of Geobotanical Published in the Journal "Physiographical Researches on Western Poland" in the Years 1948-1997. Prace Zakładu Taksonomii Roślin UAM w Poznaniu 7: 1-61.

Chmura D. \& Gucwa-Przepióra E. 2012. Interactions between arbuscular mycorrhiza and the growth of the invasive alien annual Impatiens parviflora DC: A study of forest type and soil properties in nature reserves (S Poland). Applied Soil Ecology 62: 71-80.

Chmura D., Nejfeld P., Borowska M., Woźniak G., Nowak T. \& ToKARSKA-GuZIK B. 2013. The importance of land use type in Fallopia (Reynoutria) japonica invasion in the suburban environment. Polish Journal of Ecology 61(2): 205-210.

Chybiorz R. \& Tokarska-Guzik B. 2012. BIOGEO-SILESIA - regionalny system informacji i baz danych o środowisku województwa śląskiego nowym wyzwaniem dla śląskich badaczy przyrody. Problemy środowiska i jego ochrony 20: pp. 167-171. Centrum Studiów nad Człowiekiem i Środowiskiem Uniwersytetu Śląskiego w Katowicach.

Cohn E. V., Rostański A., Tokarska-Guzik B., Trueman I. C. \& WoźNiaK G. 2001. The flora and vegetation of an old Solvay Process tip in Jaworzno (Upper Silesia, Poland). Acta Soc. Bot. Pol. 70(1): 47-60.

DAenLeR C. C. 2001. Two ways to be invader but one is more suitable for ecology. Bull. Ecol. Soc. Amer. 82: 206.

Daehler C. C. \& Carino D. A. 2000. Predicting invasive plants: prospectus for a general screening system based on current regional models. Biol. Invas. 2: 93-102.

Dewey S. A., Price K. P. \& Ramsey D. 1991. Satellite remote sensing to predict potential distribution of dyers woad (Isatis tinctoria). Weed Technology 5: 479-484.

Dorigo W., Lucieer A., Podobnikar T. \& Č Arni A. 2012. Mapping invasive Fallopia japonica by combined spectral, spatial, and temporal analysis of digital orthophotos. International Journal of Applied Earth Observation and Geoinformation 19: 185-195.

DrapiKowsKa M., LeŚNIEWSKa K., Hasterok R., SzkudLarz P., Celka Z. \& JaCKowiak B. 2013. Variability of stomata and $45 \mathrm{~S}$ and $5 \mathrm{~S}$ rDNAs loci characteristics in two species of Anthoxanthum genus: A. aristatum and A. odoratum (Poaceae). Acta Biologica Hungarica 64(3): 352-363.

DYAKowski B. 1899. Rozsiedlanie się roślin dzikich za pośrednictwem człowieka. Wszechświat 18-17: 261-265.

Esler K. J., Prozesky H., Sharma G. P. \& McGeoch M. 2010. How wide is the "knowing-doing" gap in invasion biology? Biol Invasions 12:4065-4075. DOI 10.1007/ s10530-010-9812-x 
FALIŃSKi J. B. 1966a. Antropogeniczna roślinność Puszczy Białowieskiej jako wynik synantropizacji naturalnego kompleksu leśnego. Dissert. Univers. Varsoviensis 13: 1-256.

FALIŃSKi J. B. 1971. Flora i roślinność synantropijna miast i wsi - próba analizy porównawczej In: J. B. FALIŃSKI (ed.). Synantropizacja szaty roślinnej II. Flora i roślinność synantropijna miast $\mathrm{w}$ związku $\mathrm{z}$ ich warunkami przyrodniczymi, dziejami i funkcją. Mater. Zakł. Fitosoc. Stos. Uniw. Warsz. 27: 15-37.

FALIŃSKi J. B. 1972. Synantropizacja szaty roślinnej - próba określenia istoty procesu i głównych kierunków badań. In: J. B. FALIŃSKI (ed.). Synantropizacja szaty roślinnej. III. Podstawy teoretyczne i metodyczne badań nad synantropizacją sztay roślinnej. Phytocoenosis 1(3): 157-170.

FALIŃSKI J. B. 1998a. Invasive alien plants and vegetation dynamics. In: U. StARFInGER, K. EdWARds, I. KowARIK \& M. Williamson (eds.). Plant invasions: ecological mechanisms and human responses, pp. 3-21. Backhuys Publishers, Leiden, The Netherlands.

FALIŃSKI J. B. 1998b. Maps of anthropogenic transformations of plant cover (maps of synanthropization). Phytocoenosis 10 (N. S.) Suppl. Cartogr. Geobot. 9: 15-54.

FALIŃSKI J. B. 1998c. Invasive alien plants, vegetation dynamics and neophytism. Phytocoenosis 10 (N.S.) Suppl. Cartogr. Geobot. 9: 163- 187.

FALIŃSKI J. B. 2000. The interpretation of contemporary vegetation transformations on the basis of the theories of synanthropisation and syndynamics. In: B. JACKOWIAK \& W. ŻUKOWSKI (eds.). Mechanisms of anthropogenic ahanges of the plant cover. Publications of the Department of Plant Taxonomy of the Adam Mickiewicz University 10: 9-30. Bogucki Wyd. Nauk., Poznań.

FALIŃSKI J. B. 2004. Inwazje w świecie roślin: mechanizmy, zagrożenia, projekt badań. - Phytocoenosis 16 (N. S.) Semin. Geobot. 10: 5-31.

Galera H. \& Sudnik-Wójcikowska B. 2000a. Szczególnie interesujace grupy roślin we florze Pałacu Kultury i Nauki w Warszawie. Fragm. Flor. Geobot. Polonica 7: 117-128.

Galera H. \& Sudnik-Wójcikowska B. 2000b. The flora of the Palace of Culture and Science in Warsaw. Acta Soc. Bot. Pol. 69(1): 41-54.

Geneletti D. 2004. A GIS-based decision support system to identify nature conservation priorities in an alpine valley. Land Use Policy 21: 149-160.

Góralski G., Judasz A., GaceK P., Grabowska-Joachimiak A. \& JoAсніміак A. J. 2014. Polyploidy, alien species and invasiveness in Polish angiosperms. Plant Syst. Evol. 300: 225-238.

Hulme P. E., Pyšek P., Pergl J., Jarošík V., Schaffner U. \& VILÀ M. 2013. Greater focus needed on alien plant impacts in protected areas. Conservation Letters 00: 1-7.

JACKOWIAK B. 1998a. Struktura przestrzenna flory dużego miasta. Studium metodyczno-problemowe. Prace Zakładu Taksonomii Roślin UAM w Poznaniu 8: $1-227$.

JACKOWIAK B. 1998b. The city as a centre for crystallization of the spatio-floristic system. In: J. B. FALIŃSKI, W. AdAmowski \& B. JACKOWIAK (eds.). Synanthropisation of plant cover in new Polish research. Phytocoenosis 10 (N.S.) Suppl. Cartogr. Geobot. 9: 55-67.

JACKOWIAK B. 1999. Modele ekspansji roślin synantropijnych i transgenicznych. Phytocoenosis 11(N.S.) Sem. Geobot. 6: 3-16.

JACKOWIAK B. 2000. Chorological and ecological model of urbanophilous plant in Central Europe. In: B. JACKOWIAK \& W. ŻuKowsKi (eds.). Mechanisms of anthropogenic changes of the plant cover. Publications of the Department of Plant Taxonomy of the Adam Mickiewicz University 10: 125-141. Bogucki Wyd. Nauk., Poznań.

JACKOWIAK B. 2003. Spatial structure of urban flora and its dynamism. In: A. ZAJĄC, M. ZAJĄC \& B. ZEMANEK (eds.). Phytogeographical problems of synanthropic plants, pp. 17-28. Institute of Botany, Jagiellonian University, Cracow.

Jackowiak B., Celka Z., Chmiel J., Latowski K. \& ŻUKowski W. 2013. Checklist of the vascular flora of Wielkopolska (Poland): native species and naturalized alien species. Biodiv. Res. Conserv. 31:9-96.

JACKOWIAK B. \& LATOWSKI K. 1996. Rozmieszczenie, ekologia i biologia chwastów segetalnych. Bibliografia polskich prac do roku 1995. Prace Zakładu Taksonomii Roślin UAM w Poznaniu 5: 1-111. Bogucki Wyd. Nauk., Poznań.

JACKOWIAK B. \& LATOWSKI K. 2001. Rozmieszczenie, ekologia i biologia chwastów segetalnych. Bibliografia polskich prac za lata 1996-2000. Prace Zakładu Taksonomii Roślin UAM w Poznaniu 11: 1-91. Bogucki Wyd. Nauk., Poznań.

Jeschie J. M., Gómez Aparicio L., Haider S., Heger T., Lortie C. J., PyŠEK P. \& STRayer D.L. 2012. Taxonomic bias and lack of cross-taxonomic studies in invasion biology. Front Ecol Env 349-350. doi:10.1890/12.WB.016

Kasprzyk I., Myszkowska D., Grewling Ł., Stach A., Š́moparija B., SкJŘth C. A. \& Sмith M. 2011. The occurence of Ambrosia pollen in Rzeszów, Kraków and Poznań, Poland: investigation of trends and possible transport of Ambrosia pollen from Ukraine. International Journal of Biometeorology 55: 633-644.

KĄCKI Z. \& ŚLıwiŃSKi M. 2012. The Polish Vegetation Database: structure, resources and development. Acta Soc. Bot. Pol. 81 (2): 75-79.

Keller R. P., Geist J., Jonathan M., Jeschke J. M. \& Kühn I. 2011. Invasive species in Europe: ecology, status, and policy. Environmental Sciences Europe 23, 23. DOI:10.1186/2190-4715-23-23.

KobendZA R. 1930. O kilku nowych gatunkach dla flory polskiej. Acta Soc. Bot. Pol. 7: 73-78.

KompaŁA-BĄBA A. 2013. Abiotic and biotic factors affecting the diversity of ruderal vegetation (Silesian Uplands Poland). 182 pp. Wyd. Sorus, Poznań.

KoRnAŚ J. 1955. Charakterystyka geobotaniczna Gorców. Monogr. Bot. 3: 1-216.

KORNAŚ J. 1981. Oddziaływanie człowieka na florę: mechanizmy i konsekwencje. ["Man's impact upon the flora: processes and effects"]. Wiad. Bot. 25(3): 165-182.

KoRNAŚ J. 1982. Man's impact upon the flora: processes and effects. Memorabilia zool. 37: 11-30.

KORNAŚ J. 1983. Man's impact upon the flora and vegetation in Central Europe. In: W. Holzner, M. J. A. Werger 
\& I. IKUSHIMA (eds.). Man's impact on vegetation, pp. 277-286. W. Junk, The Hague.

KornAŚ J. 1990. Plant invasions in Central Europe: historical and ecological aspects. In: DE F. CASTRI, A. J. HANSEN $\&$ M. Debussche (eds.). Invasions in Europe and the Mediterranean Basin, pp. 19-36. Kluwer Academic Publishers, Dordrecht.

KoRnAŚ J. 1996. Pięć wieków wymiany flor synantropijnych między Starym i Nowym Światem. Wiad. Bot. 40: 11-19.

Krawiecowa A. \& Rostański K. 1972. Projekt usprawnienia klasyfikacji roślin synantropijnych. Phytocoenosis. 1(3): 217-222.

Kueffer C., Pyšek P. \& Richardson D.M. 2013. Integrative invasion science: model systems, multi-site studies, focused meta-analysis and invasion syndromes. New Phytologist 200: 615-633. doi: 10.1111/nph.12415

Lambdon P. W., Pyšek P., Basnou C., Hejda M., Arianoutsou M., Essl F., Jarošík V., Pergl J., Winter M., Anastasiu P., Andriopoulos P., Bazos I., Brundu G., CelestiGrapow L., Chassot P., Delipetrou P., Josefsson M., Kark S., Klotz S., Kokkoris Y., Kühn I., Marchante H., Perglová I., Pino J., Vila M., Zikos A., Roy D. \& Hulme P. 2008. Alien flora of Europe: species diversity, temporal trends, geographical patterns and research needs. Preslia 80: 101-149.

Latowski K., Chmiel J., Jackowiak B. \& ŻUnowski W. 2010. Udział antropofitów we florze segetalnej Wielkopolski. Fragm. Agron. 27(3): 103-111.

Lenda M., Skórka P., Knops J.M.H., Moroń D., Tworek S., \& Woyciechowski M. 2011. Plant establishment and invasions: an increase in a seed disperser combined with land abandonment causes an invasion of the non-native walnut in Europe. Proc Biol Sci. Apr 22, 2012; 279(1733): 1491-1497. DOI: 10.1098/ rspb.2011.2153

Malicki M., Pielech R. \& Szczęśniak E. 2012. Przytulia turyńska Galium taurinum (L.) Scop. (Rubiaceae) nowy antropofit we florze Polski. Acta Bot. Siles. 8: 189-196.

Mooney H. A. 1999. The Global Invasive Species Program (GISP). Biol Invasions 1: 97-98.

Moraczewski I. R. \& Sudnik-WóJcikowska B. 1994. An analysis of flora synanthropization in seven Polish cities with the use of dendrites. Flora 189: 255-261.

Moroń D., Lenda M., Skórka P., Szentgyorgyi H., Settele J. \& Wojciechowski M. 2009. Wild pollinator communities are negatively affected by invasion of alien goldenrods in grassland landscapes. Biological Conservation 142: 1322-1332.

Nobis M., Nobis A. \& Nowak A. 2006. Typhetum laxmannii (Ubrizsy 1961) Nedelcu 1968 - the new plant association in Poland. Acta Soc. Bot. Pol. 75(4): 325-332.

Olaczek R. 2001. Foreword. In: A. ZająC \& M. ZajĄC (eds.). Distribution Atlas of Vascular Plants in Poland. pp. 1-4. Edited by Laboratory of Computer Chorology, Institute of Botany, Jagiellonian University, Cracow.

Pielech R., Zajaci K. \& Malicki M. 2012. Spread of Veronica filiformis (Scrophulariaceae) in the Sudetes. Biodiv. Res. Conserv. 28: 25-28.
Pimental D. (ed.). 2011. Biological Invasions: economic and environmental costs of alien plant, animal, and microbe species. $2^{\text {nd }}$ ed. 449 p. CRC Press

Piwowarski B. \& BartoszeK W. 2012. The occurrence of Glyceria striata (Lam.) Hitchc. in Europe and the new localities of the species in Poland. Acta Soc. Bot. Pol. 81(2): 109-118.

PliszKo A. 2013. A new locality of Solidago $\times$ niederederi Khek (Asteraceae) in Poland. Biodiv. Res. Conserv. 29: 57-62.

PYŠEK P. 1995. Recent trends in studies on plant invasions (1974-93). In: P. Pyšek, K. Prach, M. Rejmánek \& M. Wade (eds.), Plant invasions - General aspects and special problems, pp. 223-236, SPB Academic Publ., Amsterdam.

Pyšek P., Chytrý M., Pergl J., SÁdlo J. \& Wild J. 2012a Plant invasions in the Czech Republic: current state, introduction dynamics, invasive species and invaded habitats. Preslia 84: 576-630.

Pyšek P., Danihelka J., Sádlo J., Chrtek J. JR., Chytrý M., Jarošík V., Kaplan Z., Krahulec F., Moravcová L., Pergl J., Štajerová K. \& TichÝ L. 2012b. Catalogue of alien plants of the Czech Republic (2nd edition): checklist update, taxonomic diversity and invasion patterns. Preslia 84: 155-255.

Pyšek P., RichaRdson D. M. \& JARošík V. 2006. Who cites who in the invasion zoo: insights from an analysis of the most highly cited articles in invasion ecology. Preslia 78: 437-468.

Pyšex P., Richardson D. M., Pergl J., Jarošík V., Sixtová Z. \& Weber E. 2008. Geographical and taxonomic biases in invasion ecology. Trends in Ecology and Evolution 23: 237-244.

Pyšek P., Richardson D. M., Rejmánek M., Webster G. L., WiLLIAMSON M. \& KirSCHNER J. 2004. Alien plants in checklists and floras: towards better communication between taxonomists and ecologists. Taxon 53(1): 131-143.

Pyšek P., Lambdon P. W., Arianoutsou M., Kühn I., Pino J. \& WinTER M. 2009. Chapter 4 - Alien Vascular Plants of Europe. In: DAISIE (eds.). Handbook of Alien Species in Europe. Springer, pp. 43-61.

Rabitsch W., Essl F., Genovesi P. \& Scalera R. 2012. Streamlining European Biodiversity Indicators (SEBI): Review of SEBI indicator 10 - Invasive alien species in Europe.

ReJMÁNeK M. 1996. Species richness and resistance to invasions. In: G. H. Orians, R. Dirzo \& J. H. Cushman (eds). Diversity and processes in tropical forest ecosystems, pp. 153-172. Springer Verlag, Berlin.

Richardson D. M., Pyšek P., Rejmánek M., Barbour M. G., Panetta F. D. \& West C. J. 2000. Naturalization and invasion of alien plants: concepts and definitions. Diversity Distrib. 6: 93-107.

RostAŃSKI A. 1998a. Anthropophytes and apophytes in colonization process on the post-industrial heaps in Upper Silesia Region. In: J. B. FALiński, W. AdAmowski \& B. JACKOWIAK (eds). Synanthropisation of plant cover in new Polish research. 10. (N.S.) Phytocoenosis 9: 199-201.

RostańsKi A. 1998b. Spontaneous flora on coal heaps in Upper Silesia (Poland). In: R. W. SARSBy (ed.). 
Contaminated and derelict land. The proceedings of Green 2: The Second International Symposium on Geotechics Related to the Environment Held in Kraków, Poland, September 1997: 488-491. Thomas Telford, London.

ShIRlEy S. M. \& KARK S. 2006. Amassing Efforts against Alien Invasive Species in Europe. PLoS Biol 4(8): 1311-1313. DOI: 10.1371/journal.pbio.0040279

SimberlofF D. 2004. A rising tide of species and literature: A review of some recent books. on biological invasions. Bioscience 54: 247-254.

Soltysiak J. \& Brej T. 2014. Invasion of Fallopia Genus Plants in Urban Environment. Pol. J. Environ. Stud. 23(2): 449-458.

StęPALSKA D., SzczepaneK K. \& MyszKowsKa D. 2002. Variation in Ambrosia pollen concentration in Southern and Central Poland in 1982-1999. Aerobiologia 18: 13-22.

Sudnik-Wójcikowska B. 1998a. Czasowe i przestrzenne aspekty procesu synantropizacji flory na przykładzie wybranych miast Europy Środkowej. 167 pp. Wyd. Uniw. Warsz., Warszawa.

SudNiK-WóscikowsKa B. 1998b. The effect of temperature on the spatial diversity of urban flora. In: J. B. FAliński, W. AdAMOWski \& B. JACKowiak (eds.). Synanthropisation of plant cover in new Polish research. Phytocoenosis 10 (N.S.) Suppl. Cartogr. Geobot 9: 97-105.

SudNiK-WóJcikowska B. 2000. The role of flora in bioindication of the temperature conditions in urban areas. In: B. JACKOWIAK \& W. ŻUKOWSKI (eds.). Mechanisms of anthropogenic changes of the plant cover. Publications of the Department of Plant Taxonomy of the Adam Mickiewicz University in Poznań 10: 271-279. Bogucki Wyd. Nauk., Poznań

SudNik-WóJcikowska B. \& KoźnıewsKa B. 1988. Słownik z zakresu synantropizacji szaty roślinnej. Wyd. Uniwersytetu Warszawskiego, Warszawa.

Thuiller W., Richardson D. M., Pyšek P., Midgley G. F., Hughe G. O. \& Rouget M. 2005. Niche-based modelling as a tool for predicting the risk of alien plant invasions at a global scale. Global Change Biology 11: 2234-2250.

ToKARsKA-GuziK B. 2005. The Establishment and Spread of Alien Plant Species (Kenophytes) in the Flora of Poland. Prace naukowe Uniw. Śląskiego w Katowicach 2372: 1-192.

Tokarska-Guzik B., Chybiorz R., Parusel J. B. \& FRĄCKOWIAK J. 2014 (in press). Results of studies of nature resources as a source of spatial data for a regional information system under the auspices of the BIOGEO-SILESIA ORSIP group.

Tokarska-GuziK B., BzdęGa K., Koszela K., Żabińska I., Krzuś B., Sajan M. \& Sendek A. 2011a. Allergenic invasive plant Ambrosia artemisiifolia L. in Poland: threat and selected aspects of biology. Biodiv. Res. Conserv. 21: 39-48.

Tokarska-GuZik B., Dajdok Z., Zając M., Urbisz A. \& DANIELEWICZ W. 2011b. Identyfikacja i kategoryzacja roślin obcego pochodzenia jako podstawa działań praktycznych. In: Z. KĄCKi Z. \& E. STEFAńsKA-
KrZACZeK (eds.). Synantropizacja w dobie zmian różnorodnodności biologicznej. Acta Bot. Siles. 6: 23-53.

Tokarska-GuZik B., Dajdok Z., Zając M., ZająC A., Urbisz A., Danielewicz W. \& Hołdyński Cz. 2012. Rośliny obcego pochodzenia w Polsce ze szczególnym uwzględnieniem gatunków inwazyjnych. 197 pp. Generalna Dyrekcja Ochrony Środowiska, Warszawa.

TokARskA-GuZiK B., Węgrzynek B., Urbisz Al., Urbisz An., NowAK T. \& BzDĘGA K. 2010. Alien vascular plants in the Silesian Uplands of Poland: distribution pattern, impact and threat. Biodiv. Res. Conserv. 19: 33-54.

TRUEMAN I. 2013. Exploring the flora records. In: I. TRUEMAN, M. Poulton \& P. Reade (eds.). Flora of Birmingham and the Black Country, pp. 133-176. Pisces Publications, UK.

TYKARSKi P. 2007. Bazy danych i poziom organizmalny bioróżnorodności. Wszechświat 108(7-9): 190-196.

URBISZ AL. 2011. Occurrence of temporarily-introduced alien plant species (ephemerophytes) in Poland - scale and assessment of the phenomenon. 199 pp. Wyd. Uniw. Śląskiego, Katowice.

Vilà M., Basnou C., Pyšek P., Josefsson M., Genovesi P., Gollasch S., Nentwig W., Olenin S., Roques A., Roy D., Hulme P. H. \& DAISIE partners 2010. How well do we understand the impacts of alien species on ecosystem services? A pan-European, cross-taxa assessment. Frontiers in Ecology and the Environment 8: 135-144. http://dx.doi.org/10.1890/080083

WalczaK M. 2011. Baza danych “Obszary chronione w Polsce" - możliwości wykorzystania zawartych w niej informacji. Ochrona Środowiska i Zasobów Naturalnych 47: 163-172.

Wasowicz P., Pasierbiński A., Przedpelska-Wasowicz M. E. \& Kristinsson H. 2014. Distribution Patterns in the Native Vascular Flora of Iceland. PLoS ONE 9(7): e102916. doi:10.1371/journal.pone.0102916

WoŁkowycki D. 2000. Differentiation of ruderal floras in environmental isolation conditions. In: B. JACKOWIAK \& W. ŻuKowsKi (eds.). Mechanisms of anthropogenic changes of the plant cover. Publications of the Department of Plant Taxonomy of the Adam Mickiewicz University in Poznań 10: 111-124. Bogucki Wyd. Nauk., Poznań.

WoźniaK G. 1998. Primary succession on the sedimentation pools of coal mine. In: J. B. FALIŃSKI, W. AdAMOWSKI \& B. JACKOWIAK (eds.). Synanthropisation of plant cover in new Polish research. Phytocoenosis 10 (N.S.) Suppl. Cartogr. Geobot 9: 189-198.

Woźniak G., Chmura D., BŁońska A., Tokarska-Guzik B. \& Sierka E. 2011. Applicability of Functional Groups Concept in Analysis of Spatiotemporal Vegetation changes of Manmade Habitats. Pol. J. Environ. Stud. 20(3): 623-631.

WrZESIEŃ M. 2007. Nowe stanowiska rzadkich gatunków roślin naczyniowych na terenach kolejowych Polesia Wołyńskiego. Fragm. Flor. Geobot. Polonica 14(2): 261-269.

ZAJĄC A. 1978. Atlas of distribution of vascular plants in Poland (ATPOL). Taxon 27(5-6): 481-484. http:// dx.doi. org/10.2307/1219899 
ZAJĄC A. 1979. Pochodzenie archeofitów występujących w Polsce. Rozpr. habil. Uniw. Jagiell, 29: 1-213. Druk UJ w Krakowie.

ZająC A. 1983. Studies on the origin of archeophytes in Poland. Part I. Methodical considerations. Zeszyty Nauk. Uniw. Jagiell. 670, Prace bot. 11: 87-107.

ZAJĄC A. 1987a. Studies on the origin of archeophytes in Poland. Part II. Taxa of Mediterranean and AtlanticMediterranean origin. Zeszyty Nauk. Uniw. Jagiell. 790, Prace bot. 14: 7-50.

ZAJACC A. 1987b. Studies on the origin of archeophytes in Poland. Part III. Taxa of Irano-Turanian, Euro-SiberianIrano-Turanian and Medieterraean-Irano-Turanian origin. Zeszyty Nauk. Uniw. Jagiell. 834, Prace bot. 15: 93-129.

ZAJĄC A. 1988. Studies on the origin of archeophytes in Poland. Part IV. Taxa of Pontic-Pannonian, Mediterraneo-South Asiatic, South Asiatic and Middle
Europaean origin. Archaeophyta anthropogenea. Archaeophyta resistentia. Archaeophytes of unknown origin. Zeszyty Nauk. Uniw. Jagiell. 872, Prace bot. 17: 23-51.

ZAJĄC A. \& ZajĄC M. 2000. Processes of speciation in synanthropic floras. In: B. JACKOWIAK \& W. ŻUKOWSKI (eds.). Mechanisms of anthropogenic changes of the plant cover. Publications of the Department of Plant Taxonomy of the Adam Mickiewicz University 10: 31-38. Bogucki Wyd. Nauk., Poznań.

ZaJĄC A. \& ZaJĄC M. (eds.). 2001. Distribution Atlas of Vascular Plants in Poland. xii+714 pp. Edited by Laboratory of Computer Chorology, Institute of Botany, Jagiellonian University, Cracow.

Ziarnek K., Ziarnek M., Wolejko L. 2003. Bibliografia botaniczna Pomorza. Rośliny naczyniowe i ochrona przyrody. Publikacje z lat 1945-2000. Fundacja „Akademia Rolnicza w Szczecinie 2010”, Szczecin. 
Appendix 1. Selected papers concerning different aspects of synanthropisation and studies focusing specifically on alien plants occurring in Poland (source: Tokarska-Guzik 2005, supplemented)*

\section{Historical floras - regions, cities \& towns (in chronological order)}

- Warszawa and surrounding area (Erndtel 1730; Karo 1867; Łapczyński 1882; Cybulski 1894, 1895);

- Galicia (Galicja) (Besser 1809; Knapp 1872; Zapałowicz 1906, 1908, 1911);

- Silesia (Śląsk) (Wimmer \& Grabowski 1827, 1829; Wimmer 1841; Grabowski 1843; Fiek 1881; Schube 1903, 1904);

- Bolesławiec town and vicinity (Bytom Odrzański, Jedlina Zdrój, Oława \& Wołów) (Schneider 1837);

- Congress Kingdom of Poland (Waga 1847; Rostafiński 1872);

- $\quad$ Pomerania (Pomorze) (Klinggraeff 1848, 1854, 1866; Abromeit et al. 1898-1940; Decker 1912; Müller 1911; Holzfuss 1937; Steffen 1940);

- Poznań (Ritschl 1850);

- Kraków and surrounding area (Berdau 1859; Raciborski 1884; Krupa 1877, 1878; Żmuda 1920);

- $\quad$ Babia Góra Mt. (Zapałowicz 1880);

- Częstochowa town and surrounding area (Karo 1881);

- $\quad$ Przemyśl town and surrounding area (Kotula 1881);

- $\quad$ Tatry, Pieniny \& Western Beskidy Mts. (Berdau 1890);

\section{New alien plant species (in alphabetical order)}

Achillea crithmifolia (Dąbrowska 1972); Acorus calamus, Amaranthus retroflexus, Chamommila suaveolens, Conyza canadensis, Elodea canadensis, Galinsoga parviflora, Impatiens parviflora, Lycium barbarum, Xanthium spinosum (Kamieński 1884a, 1884b); Aegilops cylindrica (Latowski 1978); Agastache urticifolia (Guzik \& Pacyna 2003); Azolla filiculoides (Wołkowycki 1999); Barbaraea intermedia, B. verna (Mirek 1984); Bromus carinatus (Mirek 1982/1984); Chaerophyllum aureum (Oklejewicz 1999a); Chamaespartium sagittale (Kaźmierczakowa \& Tumidajowicz 1981); Corydalis lutea (Berndt 1958); Cyperus esculentus (Dajdok et al. 2007); Digitalis purpurea (Radwańska-Paryska 1950; Hantz 1993); Echinochloa microstachya subsp. microstachya (Pacyna et al. 1999); Eleusine indica (Urbisz \& Urbisz 2003); Elodea canadensis (Kamieński 1879); Elodea nuttallii (Kamiński 2010); Eragrostis multicaulis (Guzik \& SudnikWójcikowska 1994); Erechtites hieracifolia (Górski et al. 2003); Galium taurinum (Malicki et al. 2012); Glyceria striata (BabczyńskaSendek \& Sendek 1989); Impatiens capensis (Pawlaczyk \& Adamowski 1991); Lemna turionifera (Wolff \& Landolt 1994); Linaria repens (Wąsowicz 2003); Oenothera coronifera (Rostański \& Latowski 2005); Oenothera cruciata (Rostański \& Serwatka 1968); Oxybaphus nyctagineus (Ceynowa-Giełdoń 1988); Reynoutria ×bohemica (Fojcik \& Tokarska-Guzik 2000); Rubus laciniatus \& Rubus armeniacus (Zieliński 1991); Senecio inaequidens (Kwiatkowski 2011); Solidago ×niederederii (Pliszko 2013); Symphyotrichum ciliatum (Bróż \& Podgórska 2005); Vallisneria spiralis (Hutorowicz 2006); Veronica filiformis (Kornaś \& Kuc 1953); Veronica gentianoides (Oklejewicz 1997); Veronica peregrina (Zając \& Zając 1990);

\section{New alien plant species (groups of species)}

- $\quad$ new species reordered in the Warszawa province (Cybulski 1895);

- $\quad$ rare and casual plants (Trzebiński 1930);

- newcomers and wandering plants (Szulczewski 1931);

- $\quad$ newcomers in the flora of Białowieża Forest (Sokołowski 1967, 1970);

New plant community with alien plant species

Kickxietum spuriae (Kącki et al. 1999); Typhetum laxmannii (Nobis et al. 2006); Veronico-beccabungae-Mimuletum guttati (Kwiatkowski 2003);

\section{First localities}

- $\quad$ lists of plant species together with their localities (Kornaś 1950, 1954; Urbański 1958; Żukowski 1959, 1960a, 1960b; Tacik 1960; Fabiszewski \& Faliński 1963; Sowa \& Wójcik-Chrobok 1969; Rostański 1960, 1961; Schwarz 1961; Sowa 1962; Hantz 1967, 1972; Michalak 1968, 1971; Korniak 1968; Trzcińska-Tacik 1971; Michalak \& Sendek 1974-75; Głowacki 1975; Wika 1975; Olesiński \& Korniak 1980; Oklejewicz 1999b; Rostański \& Witosławski 2001; Wróbel \& Smoczyk 2001; Szczęśniak 2004; Tokarska-Guzik et al. 2010; Piwowarski \& Bartoszek 2012);

- $\quad$ kenophytes in the flora of Lublin province (Fijałkowski 1973);

- $\quad$ synanthropic and invasive grasses (Korniak 2002; Tokarska-Guzik 2003b);

\section{Synanthropic floras (in chronological order)}

- $\quad$ floras of cities: Poznań (Krawiecowa 1951); Gdańsk (Schwarz 1967); Szczecin (Ćwikliński 1970); Zielona Góra, Koszalin (Ćwikliński 1971); Łódź (Sowa 1974; Witosławski 2006); Kraków (Trzcińska-Tacik 1979);

- full cartographic description of the urban flora: Warszawa (Sudnik-Wójcikowska 1987; Sudnik-Wójcikowska \& Guzik 1998); Poznań (Jackowiak 1990, 1993); Jaworzno (Tokarska-Guzik 1999);

- $\quad$ comparison of the urban floras on the example of some cities (Krawiecowa \& Rostański 1976, 1981);

- $\quad$ floras of towns \& settlements (Mowszowicz 1960; Skowrońska 1965; Michalak 1970; Schwarz 1971; Sendek 1971; Sowa 1971; Anioł-Kwiatkowska 1974; Hantz 1974; Szmajda 1974; Czaplewska 1975; Misiewicz 1978; Sendek \& Wika 1979; Sowa \&

*List of publications cited exclusively in the Appendix 1 was placed on www.brc.amu.edu.pl 
Nasiłowski 1978; Weretelnik 1979; Sowa \& Warcholińska 1980; Misiewicz 1981; Sowa \& Warcholińska 1981a, 1981b, 1981c, 1984a, 1984b, 1987; Maciejczak 1988; Ćwikliński \& Bartnik 1990; Tokarska-Guzik \& Rostański 1997; Wąsowicz et al. 2011);

- $\quad$ ruderal floras in the rural landscape of the North Podlasie Lowlands (Wołkowycki 1997, 2000);

- $\quad$ segetal flora (Czyrsznicówna 1929; Wnuk 1976; Sowa \& Warcholińska 1979; Warcholińska 1981; Wnuk et al. 1989; Latowski 1998, 1999; Siciński 2000; Warcholińska \& Tyszkowska 2000; Latowski et al. 2010; also Jackowiak \& Latowski 1996, 2001; Misiewicz \& Piotrowski 1996; Rola 1996 and literatura cited therein);

- relics of cultivations (Celka 2011)

- $\quad$ endangered archaeophytes (Bomanowska 2010; Anioł-Kwiatkowska \& Szczęśniak 2011; Szczęśniak et al. 2011);

- regions - examples: Wielkopolska province (Szulczewski 1951; Jackowiak et al. 2013); Gorce Mts.(Kornaś 1957, 1966); Tatry Mts., the Zakopane Basin (Radwańska-Paryska 1963; Piękoś-Mirkowa \& Mirek 1978; Mirek \& Piękoś-Mirkowa 1987); Wielkopolski National Park (Szulczewski 1963; Żukowski et al. 1995); Karkonoski National Park (Rostański 1977, 1978); Lublin province (Fijałkowski 1978); Upper Silesia Industrial Region (Sendek 1981, 1984); eastern part of the Gniezno Lake District (Chmiel 1993); Zaodrze - to the West of Szczecin (Zając A. et al. 1993); Słowiński National Park (Piotrowska et al. 1997); Żuławy Wiślane (Hołdyński et al. 2001);

\section{Ruderal plant communities}

- regions (Kornaś 1952; Sowa 1971; Kompała-Bąba 2013);

- $\quad$ cities \& towns (Fijałkowski 1967; Rostański K. \& Gütte 1971; Anioł-Kwiatkowska 1974; Kępczyński \& Zienkiewicz 1974; Zając E. U. 1974; Kępczyński 1975; Czaplewska 1980; Święs \& Pleban 1981; Kucharczyk \& Kucharczyk 1983; Święs 1983);

- $\quad$ special habitats (Czaplewska 1981);

\section{Alien plants in special habitats}

- $\quad$ railways and railway stations (Meyer 1931, 1932; Kornaś et al. 1959; Sowa 1966; Krawiecowa 1968a; Ćwikliński 1968, 1974, 1984-85; Sendek 1973; Zając \& Zając 1969; Latowski 1977; Wika 1984; Nowak 1997; Wrzesień 2007);

- $\quad$ store yards (including ballast plants) (Helm 1881; Holzfuss 1936, 1941);

- $\quad$ sea \& river harbors (Rostański \& Szotkowski 1973; Misiewicz 1976, 1985, 2001);

- $\quad$ walls (Weretelnik 1973, 1982; Świerkosz 1993; Galera \& Sudnik-Wójcikowska 2000a, 2000b);

- $\quad$ field margins and fields (Dajdok \& Wuczyński 2008);

\section{Lists of alien plant species (national and regional)}

- $\quad$ kenophytes (Kornaś 1968a; Zając et al. 1998)

- $\quad$ archaeophytes (Zając \& Zając 1975; Zając 1979, 1983, 1987a, 1987b, 1988; Węgrzynek et al. 2011)

- $\quad$ ephemerophytes (Michalak 1981; Rostański \& Sowa 1986-1987; Urbisz 2011);

- American trees and shrubs (Hereźniak 1992);

- $\quad$ kenophytes of American origin (Sowa \& Warcholińska 1994);

- $\quad$ anthropophytes (Mirek et al. 1995, 2002)

- $\quad$ naturalised alien plants - neophytes (excluding archaeophytes) (Tokarska-Guzik 2003a);

- established alien plant species (kenophytes) (Tokarska-Guzik 2005);

- $\quad$ alien plants with particular reference to invasive species (Tokarska-Guzik et al. 2012)

\section{Terminology \& classification}

- classification of synanthropic plants (Kornaś 1968b, 1977a, 1977b; Krawiecowa \& Rostański 1972; Mirek 1981a; Jackowiak 1990, 1993; Tokarska-Guzik 2005; Tokarska-Guzik et al. 2011b, 2012);

- $\quad$ neophytes \& neophytism (Faliński 1968b, 1969);

- $\quad$ dictionary of synathropisation of plant cover (Sudnik-Wójcikowska \& Koźniewska 1988);

\section{Origin, history of expansion $\&$ the distribution of alien plants (in alphabetical order)}

Amaranthus (Frey 1974); Artemisia (Żukowski \& Piaszczyk 1971); Becmannia eruciformis (Frey \& Paszko 2000); Bidens melanocarpus (= B. frondosa) (Trzcińska 1961); Corydalis lutea, Cymbalaria muralis, Impatiens glandulifera (Zając \& Zając 1973); Elsholtzia ciliata (Świeboda 1963); Eragrostis pilosa (Sudnik-Wójcikowska \& Guzik 1996); Geranium sibiricum (Mirek 1981b; Ciaciura et al. 2001); Iva xanthiifolia (Guzik \& Sudnik-Wójcikowska 1989); Mimulus (Piękoś 1972); Oenothera (Rostański \& Tokarska-Guzik 1998 and literatura cited therein); Oxalis (Hantz 1979); Polygonum polystchyum (Bartoszek et al. 2006); Rumex confertus (Trzcińska-Tacik 1963); Salsola (Baradziej 1972); Trifolium patens (Loster 1972); Typha laxmanii (Baryła et al. 2005); Veronica peregrine (Zając \& Zając 1990; Guzik \& Paul 2000);

\section{Origin, history of expansion \& the distribution of alien plants (groups of species)}

- $\quad$ alien tress and shrub (Danielewicz \& Maliński 1997, 2003);

- $\quad$ alien grass species in the Silesian Upland (Tokarska-Guzik \& Nowak 2001);

- $\quad$ anthropophytes in the Vistula river valley (Kucharczyk 2003);

- $\quad$ kenophytes of the Odra riversides (Dajdok \& Kącki 2003);

\section{Invasive plants}

- $\quad$ distribution \& migration pathways (Guzikowa \& Maycock 1986; Warcholińska 1996; Trzcińska-Tacik 1996; Warcholińska \& Siciński 1996; Fabiszewski \& Kwiatkowski 2001; Tokarska-Guzik 2003b; Dajdok et al. 2003; Urbisz \& Urbisz 2006; Sobisz \& Truchan 2008; Galera \& Sudnik-Wójcikowska 2010; Bloch-Orłowska \& Żółkoś 2012); 
- $\quad$ biology, ecology, evolution and impact (Kujawa-Pawlaczyk 1991; Latowski 1995, 2005; Dajdok et al. 1998; Moroń et al. 2009; Lenda et al. 2011; Chmura \& Gucwa-Przepióra 2012; Halarewicz 2012; Zubek 2012; Chmura et al. 2013; Kohyt \& Skubała 2013);

- $\quad$ genetic and cytogenetic (Bzdęga et al. 2012; Drapikowska et al. 2013; Góralski et al. 2014);

- $\quad$ aerobiology (Stępalska et al. 2002; Kasprzyk et al. 2011);

- mechanisms \& models (Kornaś 1990; Faliński 2004);

- $\quad$ invasive plant management (Adamowski \& Keczyński 1998);

\section{Threats to protected nature by alien plant species}

- $\quad$ anthropogenic plant communities in Białowieża Forest (Faliński 1966a);

- $\quad$ neophytism in the plant cover of the Białowieża Primeval Forest (Faliński 1968b);

- $\quad$ alien plant species in natural communities (Kornaś \& Medwecka-Kornaś 1968);

- contribution of alien plant species in the flora of Opawskie Mountains (Krawiecowa 1968b);

- $\quad$ synanthropisation of forest nature reserves (Krawiecowa 1972);

- $\quad$ anthropogenic changes in plant cover of Ojców Landscape Park (Michalik 1972, 1974);

- $\quad$ the nature of the Pieniny Mts in face of the coming changes (Zarzycki 1982);

- $\quad$ weed species from Śnieżnik Massif, the Bialskie and the Złote Mts. (Brej 2001);

- $\quad$ ecological significance of kenophytes in national parks (Fabiszewski \& Brej 2008);

- alien plant species in oligotrophic habitats (Sadowska 2011);

- $\quad$ contribution of alien plant species in plant communites from the class Asplenietaea trichomanis (Świerkosz et al. 2011);

\section{General and theoretical aspects}

Faliński (1966b, 1968a, 1969, 1971, 1972, 1998a, 1998b, 2000); Kornaś (1971, 1977b, 1981, 1982, 1983, 1996; Olaczek 1972, 1974, 1982); Krawiecowa \& Rostański (1976); Sowa \& Olaczek (1978); Trojan (1982); Jackowiak (1991, 1998a, 1998b, 1999, 2000, 2003); SudnikWójcikowska (1991, 1992, 1998a, 1998b, 2000); Urbisz (1991); Moraczewski \& Sudnik-Wójcikowska (1994); Sudnik-Wójcikowska \& Moraczewski (1998); Kornaś \& Medwecka-Kornaś (2002); Wołkowycki (2003);

\section{Distribution atlases of vascular plants}

Cracow Province (Zając \& Zając 1998); Bug River Valley (Faliński et al. 2000); Poland (Zając \& Zając 2001); Atlas of alien woody species of the Białowieża primaeval forest (Adamowski et al. 2002); Łódź (Witosławski 2006); Olkusz Ore-bearing Region (Nowak et al. 2011);

\section{Popular-scientific publications}

- $\quad$ importance and role of alien plants in vegetation of the Opole province (Tokarska-Guzik \& Dajdok 2004);

- invasive alien plants of wetland ecosystems of Poland (Dajdok \&Pawlaczyk 2009);

- $\quad$ invasive plants of Lower Silesia province (Dajdok \& Śliwiński 2009);

- $\quad$ synanthropic plants (Sudnik-Wójcikowska 2011). 